cemoti $\begin{aligned} & \text { Cahiers d'études sur la Méditerranée } \\ & \text { orientale et le monde turco-iranien }\end{aligned}$

$26 \mid 1998$

L'individu en Turquie et en Iran

\title{
Citizenship and individuation in Turkey: the triumph of will over reason
}

Ayse Kadioglu

\section{(2) OpenEdition \\ 1 Journals}

Electronic version

URL: http://journals.openedition.org/cemoti/34

DOI: $10.4000 /$ cemoti.34

ISSN: 1777-5396

Publisher

AFEMOTI

Printed version

Date of publication: 1 June 1998

ISSN: 0764-9878

\section{Electronic reference}

Ayse Kadioglu, «Citizenship and individuation in Turkey: the triumph of will over reason », Cahiers d'études sur la Méditerranée orientale et le monde turco-iranien [Online], 26 | 1998, Online since 20 March 2006, connection on 08 September 2020. URL : http://journals.openedition.org/cemoti/34; DOI : https://doi.org/10.4000/cemoti.34

This text was automatically generated on 8 September 2020

Tous droits réservés 


\title{
Citizenship and individuation in Turkey: the triumph of will over reason
}

\author{
Ayse Kadioglu
}

\begin{abstract}
Enlightenment is man's emergence from his selfincurred immaturity. Immaturity is the inability to use one's own understanding without the guidance of another. This immaturity is selfincurred if its cause is not lack of understanding,

but lack of resolution and courage to use it without the guidance of another. The motto of Enlightenment is therefore: Sapere aude! Have courage to use your own understanding! Immanuel Kant ${ }^{1}$
\end{abstract}

In a short essay that I wrote in 1996, I had argued that the limitations of the feminist arguments in Turkey basically stem from an assumption that women are citizens prior to being individuals ${ }^{2}$. Feminist demands in Turkey are usually posed by way of attachment to grand social and political projects such as Kemalism, Socialism as well as Islamic identities ${ }^{3}$. Kemalist feminists emphasize women's public visibility in modern attires especially in the political arena, such as their presence and visibility in the parliament and within the political party structures. Socialist women, in the course of the 1970s emphasized a view of equality of women which came to mean "similarity with men". Hence, they denounced their sexuality and feminity and posed as "sisters" of socialist men ${ }^{4}$. Islamic women, on the other hand, have been staging a fight of the costumes since the early 1980s. With the advent of political Islam, the covered bodies of the Moslem women are perpetuated in stark contrast with the bodies of modern women. These women resort to veiling in order to emphasize their personality rather than sexuality ${ }^{5}$. Veiling has become a way of denouncing sexuality outside of the confines of a marital arrangement. In the course of serving such grand social and political projects, then, Turkish women have subordinated their individual identities. 
The trajectory of Turkish men is not too different from that of Turkish women in terms of the subordination of individuality. Hence, Turkish men and women, first and foremost perceive themselves first and foremost as Turkish citizens who have the responsibility of performing certain duties.

In the course of the past couple of years, there has been an increase in academic efforts in the West to critically examine and perhaps redefine the notion of modern citizenship. Feminist literature contributed a great deal to academic discussions on the notion of citizenship. Today, the notion of modern citizenship is in the process of getting divorced from its attachment to the nation-state. In other words, we live in an era in which increasing demands here are to open up the public realm to differences that were previously relegated into the private realm. These demands for opening up the public realm to differences involve women, immigrants, blacks, as well as ethnic and religious groups.

3 In this article I will first present a brief review of the existing literature that classifies and critically discusses the modern notion of citizenship, keeping a particular eye on the Turkish notion of citizenship. The main thesis of this article is that "the citizen precedes the individual" in Turkey. In other words, as it is expressed in the title, "will triumphed over reason" in the Turkish context. Secondly, the article attempts at portraying the validity of this thesis by referring to the works of a self-proclaimed Turkish liberal, Ahmet Agaoglu, who elaborated on the concept of the individual in Turkey in the 1930s.

4 The notions of citizenship and individualism can be studied in various ways. One could study Constitutions and other legal documents, such as property laws in order to delineate the category of citizenship in a particular context. One could also study certain critical texts written by philosophers, political thinkers or founders of a political regime, that focus on the "concepts" of citizenship and individualism. The following discussion approaches the notions of citizenship and individualism from the latter angle.

\section{The citizenship problematique}

5 The roots of the modern concept of citizenship can be located in the French Revolution. It evolved along with the evolution of various nationalisms in Europe in the aftermath of the French Revolution. The beginnings of immigration control in Europe were an outcome of the French Revolution. In England, for instance, the 1792 Aliens Bill was a direct response to the flight of French refugees (about eight thousand) from the Revolution ${ }^{6}$. In America and Switzerland, too, immigration control began as a reaction to the French Revolution and fears that Jacobin emissaries had infiltrated immigrant groups.

6 The modern concept of citizen is closely associated with the movement from rural areas to urban centers. A citizen is someone from the civitas (city). In the course of the eighteenth century, the city was a place where individual freedoms were pushed to the forefront and feudal hierarchical structures were destroyed. Citizenship was the motor of these changes away from feudal bondage relations towards capitalist contractual relations. The nineteenth century, on the contrary, was characterized by many romantic views of the city as the center of decadence and deterioration. 
7 Today, with the increasing scrutiny of the basic categories of modernity, the modern notion of citizenship has begun to be viewed outside of its attachment to the nationstate. The current need to revise the category of citizenship is a consequence of the process of globalization. Globalization and the transfer of images and populations across countries has prompted the opening up of the public realm to differences that were earlier relegated to the private realm. Such differences are usually expressed in terms of discourses pertaining to gender, race, religion, and ethnicity. At the advent of the twenty first century, the notion of citizenship is going through a transformation along with other conceptual searches within democratic theory. The decline of the supremacy of nation states has captured the attention of many researchers, who emphasizes the increasing importance of regional cooperation as well as globalization. However, Europe has simultaneously been witnessing a remarkable resurgence of nationalism as well. Hence, our times are characterized by conflicting trends which signal the demise of the nation-state as well as the resurgence of nationalisms. Perhaps, one of the distinguishing features of our times is a conflict duality involving the lowering of established barriers to communication among the peoples of the world and, at the same time, the erection of new ones. Hence, while some of the historical reasons that have paved the way to nationalism and xenophobia in the European context are being eliminated, new ones are mushrooming in political cultures laden with racial motifs ${ }^{7}$. The debates regarding citizenship are also revolving around similar themes. On the one hand, there are arguments regarding the dissolution of the modern concept of citizenships along with the nation state, and its replacement by the larger category of human rights and, on the other, there are yearnings for pre-modern, organic communities as the basis of citizenship, along with authoritarian nationalisms. Hence, while the modern notion of citizenship is widening into human rights, it is, at the same time, getting narrower, with the increasing salience of identity politics, and with an urge to glorify private identities. Thus, a revision and redefinition of the modern notion of citizenship involves a "rearticulation of the public and private realms" that were separated in modernity and were fused in pre-modern societies ${ }^{8}$.

In the Turkish context, the urge to revise and redefine the notion of citizenship as arisen from a visible accentuation of the expression of women's as well as Islamic and Kurdish identities, since the late 1980s. Such differences which were previosuly relegated into the private real, begun to make their presence felt in the public realm. The absolute, homogeneous, all-encompassing category of Turkish citizenship has been demystified and has begun to crumble due to the predominance of an "identity politics" in Turkey, based on gender-related, religious and ethnic identities. While this issue has been attracting increasing attention in academic circles", a new notion referred as "Constitutional citizenship" has begun to be discussed in the political circles with the expression even being used by the President, Süleyman Demirel ${ }^{10}$. In the midst of these debates on Turkish citizenship, some people have begun to say of themselves "I am from Turkey"(Türkiye'liyim), rather than "I am a Turk" (Türküm). This symbolized the demystification of the official view of Turkish citizenship embodied in Mustafa Kemal Atatürk's famous expression "How happy is the one who calls himself a Turk!" (Ne mutlu Türküm diyene!). I believe that the issue of citizenship poses the question of democratization in Turkey from the angle of modernity rather than focusing on the specific features and problems of the Turkish modernization project. The scrutiny of the modern notion of citizenship is not peculiar to Turkey. It is a 
process that was unleashed all over the world as a result of a dynamics set in play by globalization.

\section{Classifications of modern citizenship}

Almost all the new analyses of the modern notion of citizenship in the literature refer to T. H. Marshall's classical works ${ }^{11}$. Marshall refers to three dimensions of citizenship: civil/legal, political, and social. Firstly civil/legal rights of citizens evolved in the course of the seventeenth century vis a vis the absolutist states. Accordingly, courts and individual legal rights began to appear. Secondly, political rights evolved in the course of the eighteenth and nineteenth centuries alongside the evolution of modern parliamentary systems. Thirdly, the social dimension of citizenship is a phenomenon of the twentieth century and is related to the welfare state. This dimension had paved the way to certain social rights of individuals, such as unemployment, health, and education. Marshall, then, pointed to a uniform, evolutionary and teleological history of the notion of citizenship. As a result, his citizenship theory has been criticized extensively in the recent literature for failing to account for various types of modern citizenship ${ }^{12}$.

Still, the sequence in the emergence of the three dimensions of citizenship can be utilized in accounting for different trajectories towards modern citizenship. In cases where democratization preceded bureaucratization, civil and legal rights have acquired predominance, to the detriment of social rights. In the United States, for instance, the notion of "social citizenship" is an oxymoron ${ }^{13}$. Citizens relate to the state either via contractual arrangements or they receive aid from the state in the form of charity. Hence, the recipients of welfare, state benefits are usually viewed as lazy parasites who are unworthy of the honor of citizenship. Quite contrarily, in Germany, and most other Western European countries where bureaucratization preceded democratization, citizens (the members of the Volk) benefit from welfare state provisions as "rights". In Turkey, the distinguishing feature of civil, legal, political and social rights is the fact that they were given from above, rather than acquired as rights in the aftermath of demands and struggles from below. Hence, citizenship was given from above prior to the birth of a bourgeoisie which posed demands and ignited the fire that culminated in constitutionalism ${ }^{14}$.

11 In what follows, three major classifications of the modern notion of citizenship that have appeared in the recent literature will be reviewed, while keeping an eye on the trajectory of Turkish citizenship.

\section{Different Nationalisms, Different Conceptions of Citizenship}

12 The years between 1789 and 1815 signaled the emergence of both French and German nationalisms ${ }^{15}$. German nationalism emerged alongside a cultural movement, i.e. Romanticism. One of the most distinguishing features of this tradition was its critical attitude towards French cosmopolitanism. German Romantics thought that the rationalism of the eighteenth century was artificial. They relied on intuitions and emotions rather than reason and intellect. The German Romantic movement revealed the dark and anti-rational aspects of German nationalism. The notion of a German nation that evolved in the course of the nineteenth century stemmed from a Volkisch 
ideology which later formed the basis of the National Socialist worldview. The German Romantic literature became the medium for the expression of German nationalism in the nineteenth century, prior to the formation of a German nation-state. Since German nationalism preceded the nation-state, it was expressed in ethnic and cultural terms. Accordingly, William Rogers Brubaker refers to an "ethnocultural conception of nationhood" in Germany ${ }^{16}$. In comparing the German and French conceptions of nationhood and citizenship, Brubaker says:

It is one thing to want to make all citizens of Utopia speak Utopian, and quite another to want to make all Utopiphones citizens of Utopia. Crudely put, the former represents the French, the latter the German model of nationhood. Whether juridical (as in naturalization) or cultural, assimilation presupposes a political conception of membership and the belief, which France took over from the Roman tradition, that the state can turn strangers into citizens, peasants -or immigrant workers- into Frenchmen ${ }^{17}$.

13 Hence, while the French conception of citizenship evolved in an assimilationist and state-centered manner, the German conception acquired an organic, differentialist, dissimilationist and Volk-centered character. French nationhood evolved in a predominantly political way, while the German one became predominantly ethnocultural. As Brubaker puts it:

In fact, traditions of nationhood have political and cultural components in both countries. These components have been closely integrated in France, where political unity has been understood as constitutive, cultural unity as expressive of nationhood. In the German tradition, in contrast, political and ethnocultural aspects of nationhood have stood in tension with one another, serving as the basis for competing conceptions of nationhood. One such conception is sharply opposed to the French conception: according to this view, ethnocultural unity is constitutive, political unity expressive, of nationhood ${ }^{18}$.

14 Hence, the temporal distance between the state formation and nation-building processes, as well as their sequence, gave shape to the different conceptions of nationhood and citizenship in France and Germany ${ }^{19}$. Since French nationalism appeared at about the same time as the French nation-state, political and social unity was the work of statesmen. German nationalism preceded by half a century the formation of the German nation-state. The German Romantic tradition was laden with motifs of yearning for a national state. Such a temporal distance made ethnic and cultural unity constitutive of German nationalism. This paved the way to the significance laid on blood ties and/or descent as the basis of modern German citizenship.

15 The distinction between the French and German nationalisms and conceptualizations of citizenship is significant in understanding Turkish nationalism in two aspects: First of all, Turkish nationalism displays the characteristics of both French and German nationalisms - it embraces both Civilization and Culture. Hence it has a paradoxical nature ${ }^{20}$. The paradox between Civilization and Culture is nowhere better expressed than in the writings of Ziya Gökalp. The type of nationalism that Ziya Gökalp mentioned in his writings was individualist and cosmopolitan, yet it also espoused the retainment of a local, pristine identity. Thus, the concepts of Civilization and Culture were not antithetical, mutually exclusive entities in Ziya Gökalp's thought. Rather he tried to synthesize them. Niyazi Berkes in his analysis of Ziya Gökalp's thought maintains that: 
If his analyses are taken as a whole, however, these two concepts (Culture and Civilization) do not represent antithetical and mutually exclusive entities, but rather two closely related and complementary traits of social reality...Civilizational elements assume meaning and function in the life of men only when they enter into the service of culture. Without a cultural basis, civilization becomes merely a matter of mechanical imitation; it never penetrates into the inner life of a people

and never gives fruit of any kind ${ }^{21}$.

Secondly, it is important to point to the sequence of the emergence of the state and nation in Turkey. Whereas in the German case, it is possible to refer to a nation preceding a state (i.e. "a nation in search of its state"), in the Turkish context, the historical order of things was reversed. In the case of modern Republican Turkey, one can refer to a state preceding a nation (i.e. "a state in search of its nation") ${ }^{22}$. Hence, state-political unity appears as the constitutive unit of the Turkish nation-state. In short, the indivisibility of the Turkish state with its nation, and the irreversibility of the borders -contrary to the case in Germany- constitutes the cornerstone of Turkish national identity. Hence, Turkish citizenship appears as a notion defined from above by the state authorities. The distinguishing features of this notion of citizenship were delineated in the 1931 Congress of the Republican People's Party and were formulated as the "six arrows", which became the insignia of the Party. These were: Nationalism, Secularism, Populism, Republicanism, Etatism, and Revolutionism. These principles were introduced to the Constitution by 1937 and Turkish citizens were expected to internalize them.

\section{Liberal-Individualism and Civic-Republicanism}

There exists another classification of the modern notion of citizenship in the literature. This classification stems from a philosophical distinction between the liberal or liberalindividualist traditions and the classical or civic-republican tradition. Adrian Oldfield, who classifies modern citizenship on the basis of these philosophical traditions, refers to the differences between citizenship as "status" and citizenship as "practice" 23 . Liberal-individualism has been the dominant strain of thought in Anglo-American political theory since seventeenth century, roughly from Hobbes onwards. According to oldfield, liberal individualism accords the individual an ontological, epistemological and moral priority ${ }^{24}$. Liberal individualism defines citizenship as a status on the basis of "rights", and hence gives rise to a language of citizenship in terms of needs and entitlements. "The status of citizenship" imposes no "duties" the individuals beyond the minimally civic ones. Individuals relate to each other on a contractual basis. Any other form of public involvement and political activity is their "choice". Hence, in the liberal-individualist tradition, the conception of citizenship generates no social bond other than contract. It does not prompt any type of social solidarity, cohesion, or sense of common purpose ${ }^{25}$. It produces an individual who is deficient and impoverished as a social being.

18 The classical or the civic-republican tradition has its origins in the ethical and political thought of Aristotle. It was reinforced and modified by a succession of political thinkers from Macchiavelli to Rousseau and beyond. In the words of Oldfield, "it addresses much more cogently the twin themes of citizenship and community" ${ }^{26}$. In the classical tradition, citizenship appears as an activity or a practice such that not to engage in the practice is, in important senses, not to be a citizen ${ }^{27}$. Citizenship, in this tradition, is 
expressed in terms of a language of duties and/or obligations to the community. Practices empower individuals to act like citizens. It is the shared commitment to these practices what makes individuals citizens. It is action in such spheres as military service, which is both constitutive of citizenship and sustaining of the community of which the citizen is a member. In this view, individuals are not thought of as logically prior to society ${ }^{28}$. Moreover, they have no moral priority. As a result, claims may be made on their time, resources, and lives for the morally superior entity which is the community ${ }^{29}$. Oldfield's major endeavor is to achieve an articulation between these two different traditions and redefine the notion of modern citizenship by drawing the good aspects of each. As he puts it:

In the Western world, the ideal of citizenship as status is one which it is not difficult to think of as achievable, even if vigilance is required to ensure that the achievement is sustained. Our confidence here is in large part a product of the sheer amount of thought and struggle which have been invested in the ideal. The same cannot be said of the ideal of citizenship as practice, and in large part this reflects the very success of the liberal-individualist achievement, which was to liberate the individual from the constricting influences of society and the state. The thinking has been there, but the struggle has not. The question, therefore, is whether the struggle is worthwhile. We must not expect to displace the idea of citizenship as status, but we can use elements of this conception to further the project of citizenship as practice ${ }^{30}$.

In the aftermath of the proclamation of the Republic the Turkish notion of citizenship evolved in a manner that is more akin to the civic-republican tradition. Accordingly, Turkish citizenship is based more on "duties" than on "rights". In a study surveying the books utilized in citizenship education courses in primary and secondary schools in Turkey in the Republican era, Füsun Üstel underlines the evolution of a notion of citizenship based on duties ${ }^{31}$. Accordingly, the most important aim of citizenship education is the achievement of civilization and the inculcation of patriotism. Üstel refers to a "militant" citizen who evolved until the end of the 1940s, and who was "burdened with duties" 32 .

21 Fuat Keyman presents a notion of Republican citizenship that is constituted of duties on the basis (in order to promote a "common good"), to the detriment of individual rights $^{33}$. He interprets the concept of citizenship in Turkey within the framework of the Platonic nature of the Kemalist project of modernity. Accordingly, "common good" is defined by reference to a "will to civilization" on the part of the state elites. Hence, politics in this context does not entail an articulation of different demands into the decision-making process, and, therefore, their representation, but rather the steering of society towards a common good defined by the state elite in accordance with their will to civilization. This common good has ontological priority over demands coming from the society ${ }^{34}$. As a result, the citizen appears both as the object of the Kemalist modernization project and its carrier. She is not only expected to internalize this project but also reproduces the sovereign dominant of the state ${ }^{35}$.

\section{Modern Citizenship along on the Axes of Active-Passive and Private- Public}

Bryan Turner forwards a classification of the modern notion of citizenship based on the two axes of active versus passive, and the extent of its definition within the public 
realm ${ }^{36}$. Turner's analysis contains a critique of Marshall's evolutionary and uniform trajectory of modern citizenship. As he puts it:

The point of this historical sketch has been partly to provide a critique of the monolithic and unified conception of citizenship in Marshall and partly to offer a sociological model of citizenship along two axes, namely public and private definitions of moral activity in terms of the creation of a public space of political activity, and active and passive forms of whether the citizen is conceptualized as merely a subject of an absolute authority or as an active political agent ${ }^{37}$. which have evolved in four different contexts. First of all, in revolutionary contexts, citizenship involves a struggle from below (active citizenship) with an emphasis on the public arena (citizenship evolved in the public realm). As a result, the private world of the individual is regarded with suspicion. Second, in the liberal pluralist context, citizenships, once again involves a struggle for rights from below (active citizenship), yet there also exists a continuous emphasis on the rights of the individual for privatized dissent (citizenship evolved in the private realm). Third, in passive democratic mediums, citizenship rights are given from above without, or prior to, a struggle from below (passive citizenship or citizen as subject), combined with a legitimacy of representative institutions, courts and the welfare state system (citizenship evolved in the public realm). Fourth, in plebscitary authoritarian mediums, citizenship rights are once again given from above (passive citizenship). Yet, although the state invites the citizens to periodically elect a leader, the latter is no longer responsible to the electorate on a daily basis, and therefore private life emerges as a "sanctuary from state regulation" (citizenship evolved in the private realm) ${ }^{38}$.

Turner refers to the French conception of citizenship within the revolutionary tradition, where there existed an attack on the private space of the family and religion. The American conception of citizenship contained motifs of the liberal pluralist solution since participation was emphasized yet contained by a continuous emphasis on the privacy and the sacredness of individual opinion. Tne English case was, under the seventeenth century settlement, in Turner's opinion, an example of the passive democratic solution, since citizens appeared as mere subject combined with a legitimacy of the representative institutions. German fascism constitutes a degeneration of plebscitary democracy, where "the individual citizen is submerged in the sacredness of the state, which permits minimal participation in terms of election of leaders, while family life is given priority in the arena of personal ethical development" 39. The failure of a radical bourgeois revolution in Germany in the 1840s, and the realization of unification from above in 1870 by means of Bismarckian legislation, paved the way to passive citizenship which became the main carrier of social rights. The absence of a successful liberal revolution produced an underdeveloped public realm in Germany ${ }^{40}$.

The Turkish conception of modern citizenship, when viewed from the angle of Turner's classification, seems akin both to the revolutionary French tradition - since there exists an attack on the private space of the family and religion - and the German passive tradition. In Turner's formulation, the former tradition may collapse into totalitarianism when the "state in pushing egalitarianism to the extreme closes off the private sphere from influencing the course of political affairs" ${ }^{41}$. The Turkish conception differs from the French one in that it was defined from above and therefore was passive. It is similar to the German conception in that the absence of a successful 
liberal revolution - and hence participation - produced an underdeveloped public realm. Turkish citizenship was defined from above (passive), within an exaggerated public space smothered the individual and invade the private space of the family and religion. Üstel observes an effort to supervise and regulate the private realm in citizenship education for example in the listing of appropriate fun and recreational activities, the regulation of health and hygiene, as well as dress codes, until the end of the $1940 \mathrm{~s}^{42}$.

Perhaps what distinguishes the Turkish notion of citizenship from the French tradition is the absence of Enlightenment prior to the establishment of citizenship. If, following Immanuel Kant, Enlightenment is defined as "man's emergence from his self-incurred immaturity", then we might say that the Turkish notion of citizenship precludes an unenlightened, immature individual ${ }^{43}$. Hence, the notion of Turkish citizenship was constructed on the basis of an enlightened, "free" individual capable of producing demands. Such a notion purports to steer the common lives of immature beings by means of duties. The citizens are not expected to reason. Rather, they are expected to follow. In elaborating on national morals, Atatürk says:

In a nation which is developed and has reached a perfect level, the requirements of national morals are undertaken by the individuals in that nation -without resorting to reason- by means of the voice of their conscience and emotional instinct ${ }^{44}$.

Writing in 1929-30, Atatürk acknowledged the immature state of the Republic and argued that what is usually relegated to individual initiative in developed countries should be considered as vital state undertakings in the country. As he put it:

Our Republic is very young; it is not yet capable of contemporary undertakings and all the grand tasks that it inherited from the past. As in political and intellectual life, in economic undertakings too, it would not be correct to wait for the results of individual initiatives. The significant and grand tasks should be realized in a successful way only by a government that relies on national wealth and organizes the dispensing and bearing of national sovereignty by relying on all the institutions and power of the state ${ }^{45}$.

Ironically, the state elite's will to civilization hardly received any fundamental criticisms from the liberal opposition in Turkey in the 1930s. The priority of will over reason is also evident in some of the liberal texts of that era. In what follows, I will fortify this argument by briefly focusing on the liberalism and peculiar individualism of Ahmet Agaoglu ${ }^{46}$.

\section{Limits of individualism}

Ahmet Agaoglu (1869-1939) is one of the most interesting thinkers of the early Republican era. He was actively involved in the formation of a legitimate opposition party, the Free Republican Party (Serbest Firka) in 1930, which lasted less than four months. The Free Republican Party was founded upon the wishes of Atatürk who wanted to create a controlled opposition. In his memoirs, Agaoglu describes how he was given the task of being among the founders of such a party ${ }^{47}$. The Free Republican Party's political impact remained quite limited but the impact of the whole experience on Agaoglu's thought was quite significant. He never returned to the ranks of the Republican People's Party (Cumhuriyet Halk Firkasi) after this episode. He spent his final years producing a fascinating literature in terms of a peculiar brand of liberalism. 
30 In his search for the causes of the backwardness of Ottoman society, Agaoglu laid primary emphasis on the lack of individualism in the Ottoman culture. He thought that in the East, in general, individuals were not given the opportunity to live. Rather, they were drowned under despotic regimes:

In the East, the individual was drowned, in the West he had unclosed himself; the individual was squeezed, weakened, and made into a meager being under an increasingly ferocious despotism and put into his own narrow and constricted sheath. In the West, on the other hand, the individual gradually took a hold of his freedoms and, by constantly opening up, felt the pleasure of living and working as a result of the weakening of despotism. As a result, the Oriental societies composed of constricted individuals put into their own sheath also became constricted and weakened ${ }^{48}$. his hope, rather, on the adoption of certain moral values since he thought despotic frames of mind lingered on in the Turkish Republic despite the Kemalist reforms ${ }^{53}$. Such a moral, virtuous individual was rather to be created by two methods: First of all, Agaoglu placed a lot of importance on the role of the leading literary figures, such as poets, novelists and intellectuals of his time. He considered literary figures and intellectuals to be motors of progress. Accordingly, he at times voiced a major disillusionment with the works of such figures in the Ottoman-Turkish lands ${ }^{54}$. His 
elitism is nowhere more clearly expressed than in his utopian novel, Serbest Insanlar Ülkesinde (In the Land of the Free Men). ${ }^{55}$ Here, he describes the process through which an egoist individual becomes a selfless man. All along, he is guided by a group of intellectuals which he refers as the "pir"s. Hence, Agaoglu's individualism contains elitist motifs.

Secondly, the selfless individuals were to be created by their own internal self. Inner self was expected to tame the outer self. At this point, Agaoglu's thought was influenced by the works of Henri Bergson, which had a metaphysical dimension. ${ }^{56}$ The Turkish followers of Bergson in their journal, Dergah, argued that, the secret of success of the War of Independence was to do with more than just technical advances in the military. It was not something that could be measured by the categories of positive sciences. Rather such a success spilled from a basic instinct of all living creatures which was called élan vital (elan of life).

In a fascinating book, where he described the life and works of his father's friends, Ahmet Agaoglu's late son, Samet Agaoglu, pointed to a difference between his father's and Ziya Gökalp's ideas. ${ }^{57} \mathrm{He}$ argued that in Ziya Gökalp's thought, the individual had to surrender to the state entity - hence there were no rights but only duties. Agaoglu, on the other hand, brought the individual to the forefront, outside of the realm of the state. Nevertheless, he still placed more emphasis on duties than on rights. What distinguished Agaoglu was his vision of an individual who would eventually be aware of his duties through the efforts of his own inner self. Hence, Agaoglu underlined the significance of will over reason. Since spirit was made up of both reason and will, reason had to give in to will for the achievement of a solidarist social structure composed of selfless, responsible individuals. Given all his descriptions of dutyoriented, moral, selfless individuals led by "pir"s, Agaoglu's land of the free man seems rather like a dystopia where moral despotism reigns. The selfless individuals of this puritan free land seem to have gone through what he calls the three types of cleanliness cleansing of the body, heart, and spirit ${ }^{58}$.

It is obvious that Agaoglu's individualism carried both elitist and solidarist motifs due to its emphasis on the intellectuals and altruism at the expense of egoism. His individual was not someone who was expected to use his reason but rather was to be dragged to an "ordered freedom" under the guidance of intellectual leaders ${ }^{59}$.

\section{Conclusion}

The main contention of this article is that, in the Turkish context, the concept of modern citizenship evolved in such a way as to exclude a liberal individualist dimension. Whereas in Western Europe the notion of the individual appeared in philosophical writings prior to the emergence of modern citizenship, in Turkey the citizen precedes the individual. Hence, Turkish citizens found themselves to be absorbed in grand social projects such as Kemalism, Socialism, and political Islam. Trapped in the missions of such projects, they were unable to recognize the significance of becoming an individual prior to becoming a Kemalist, Socialist, and political Islamist.

In Turkey, the civil and legal, political and social rights associated with citizenship were given from above. They were not acquired as a result of struggles from below. The notion of Turkish citizenship evolved within the civic republican tradition by 
emphasizing practices that were viewed as duties. In the early years of the Republic, Turkish citizens were geared towards embracing the fundamental tenets of the Turkish revolution, namely, Nationalism, Secularism, Populism, Republicanism, Etatism, and Revolutionism. The association of such aspects of the Republican ideology with citizenship paved the way to its definition by disregarding a distinction between the public and the private realms. The Republican elite defined, not only the public duties of the citizens, but also their private roles, dress codes, and their recreational activities. It is then possible to argue that the notion of Turkish citizenship was defined from above by the Republican elite, by disregarding the privacy of the individuals. In sum, in the founding years of the Republic, Turkish citizenship was defined from above by a state elite within the civic Republican tradition, by emphasizing duties over rights and by disregarding the privacy of the individual. Ironically, the Republican epistemology shaped the contours of the liberal arguments in the Turkish context as well. One of the self-acclaimed liberals of the 1930s, Ahmet Agaoglu, for instance, formulated an individualism which was delimited by a Republican epistemology. This epistemology had two distinguishing features: First of all, it was essentialist, i.e. it was based on an essentialist distinction between the East and the West and/or the Orient and the Occident. Secondly, it was based on a managerial attitude on the part of the Republican elite who identified civilization as a societal goal, and who initiated a process of social engineering geared towards constructing a modern national identity at the expense of traditional, local, religious identities ${ }^{60}$. Agaoglu's liberalism, defined within the confines of a Republican epistemology was laden with positivist, vanguardist, solidarist, and moralist motifs. The characteristics of Agaoglu's individual, were quite akin to the Republican citizen who was a militant follower rather than a reflecting, reasoning being.

In sum, the Republican citizen expected to "follow" rather than reach certain decisions via his/her own reflection, was the subject of another will. According to Hans Reiss, who interpreted Kant's definitive study on Enlightenment:

He (Kant) does not consider it to be the purpose of politics to make people happy. Happiness is subjective...This argument, of course, does not mean that he does not wish people to be happy. It only means that political arrangements should not be organized in such a way as to aim at promoting happiness, but that they should permit men to attain happiness in their own way ${ }^{61}$.

Accordingly, Turkish citizens were discouraged from pursuing their own happiness. Rather, they were integrated into a grand civilizational design which was believed to promote happiness. The individual defined in some liberal texts was quite delimited and was not that different from the citizen envisioned by the state elite. Hence, a political culture that prompted the will to follow rather than the courage to reason began to evolve in the Turkish Republic. Will triumphed over reason. Perhaps the most revealing metaphor pertaining to the triumph of will over reason in Turkey is the place deemed appropriate for the replica of Auguste Rodin's notorious sculpture, The Thinker, which represents a naked, reflecting men. The most distinguished Turkish replica of The Thinker resides in the yard of a mental hospital in Istanbul, as if signifying a tribute to the discouragement of a naked moment of reflection (enlightenment tradition) in Turkey. 


\section{NOTES}

1. Immanuel Kant, "An Answer to the Question: What is Enlightenment?", Hans Reiss (ed.), Kant's Political Writings, Cambridge University Press, Cambridge, London, New York, , New Rochelle, Melbourne, Sydney, 1970.

2. Ayse Kadioglu, "Cumhuriyet Kadini: Vatandas mi, Birey mi?" (Republican Woman: a Citizen or an Individual), Varlik, 1069, October 1996, pp. 12-15.

3. See, Ayse Kadioglu, "Alaturkalik ile Dffetsizlik Arasinda Birey Olarak Kadin" (Women as Individuals -Between Being Traditional and Unchaste), Görüs, 9, May 1993, pp.58-62.

4. Fatmagül Berktay, "Türkiye Solu'nun Kadina Bakisi: Degisen Bir Wey Var mi?" (Turkish Left's View of Women: Has There Been a Change?), Wirin Tekeli (ed.), Kadin Bakis Açisindan 1980'ler Türkiye'sinde Kadinlar (An Account of Women By Women in Turkey in the 1980s), Iletisim Publications, Istanbul, 1990.

5. Nilüfer Göle, Modern Mahrem: Medeniyet ve Örtünme (Modern Privacy: Civilization and the Veil), Metis Publications, Istanbul, 1991, p.125. See also, Ayse Kadioglu, "Women's Subordination in Turkey: Is Islam Really the Villain?", Middle East Journal, 48/4, Autumn 1994, pp. 645-661, for a review of issues on Turkish women and Islam.

6. Richard Plender, International Migration Law, A.W. Sijthoff, Leiden, p. 43.

7. In an earlier article, I have referred to the coexistence of globalization and "Germanization" (exclusionary and non-integrationist attitudes towards the Other) as the two paradoxical trends of our times. Ayse Kadioglu, "Devletini Arayan Millet: Almanya Örnegi" (A Nation in Search of its State: The German Case), Toplum ve Bilim, 62, Fall 1993, pp. 95-111.

8. Ayse Kadioglu. "Kamusal Alan ile Özel Alanin Yeniden Eklemlenmesi: Demokratik Vatandaslik" (Rearticulation of the Public and the Private Realms: Democratic Citizenship), Diyalog, 1, 1996, pp. 119-134.

9. Many international and national conferences held in Turkey were organized around the themes of citizenship, identity, multiculturalism...etc., especially in the latter half of the 1990s. There was a pioneer international symposium organized by the Marmara University, International Relations Center in Istanbul on March 28-29, 1996 titled Redefinition of Nation, State and Citizenship. A subsequent national conference was organized by Ege Universiy in Izmir on April 10-12, 1996 titled Republic, Democracy and Identity. [The papers were collected in a book titled Cumhuriyet, Demokrasi ve Kimlik (Republic, Democracy and Identity), edited by Nuri Bilgin, Baglam Yayinlari, Istanbul, 1997].A similar international conference was organized by Mersin University and Deutsch-Türkische Vereingung zum Sozial-und Geisteswissenschaftliche Austausch in Mersin on October 28-November 1, 1997 titled Multiculturalism, Immigration and Globalization.

10. On the debates on "Constitutional citizenship" in Turkey, see, Nur Vergin, "Anayasal Vatandaslik Ne Demektir?" (What is the Meaning of Constitutional Citizenship?), Milliyet (daily), December 28, 1996. See also, Füsun Üstel, "Anayasal Vatandaslik Hangi Anayasaya Vatandaslik?" (Constitutional Citizenship According to Which Constitution?), Radikal (daily), December 17, 1996.

11. T. H. Marshall, Citizenship and Social Class and Other Essays, Cambridge University Press, Cambridge, 1950; T. H. Marshall, Class, Citizenship and Social Development, University of Chicago Press, Chicago and London, 1977.

12. See, for instance, Bryan Turner, "Outline of a Theory of Citizenship", Chantal Mouffe (ed.), Dimensions of Radical Democracy: Pluralism, Citizenship, Community, Verso, London, New York, 1992, pp. 33-63. See also, Bryan Turner (ed.), Citizenship and Social Theory, Sage Publications, 
London, Newbury Park, New Delhi, 1993; Bart van Steenbergen (ed.), The Condition of Citizenship, Sage Publications, London, Thousand Oaks, New Delhi, 1994.

13. Nancy Fraser and Linda Gordon, "Civil Citizenship Against Social Citizenship? On the Ideology of Contract-versus-Charity", Bart van Steenbergen (ed.), The Condition of Citizenship, Sage Publications, London, Thousand Oaks, New Delhi, 1994.

14. Hasan Bülent Kahraman refers to the construction of all the Marshallian aspects of citizenship in Turkey "in a dash", rather than its gradual "completion" as a process. Hasan Bülent Kahraman, "Kemalist Cumhuriyetçilik, Yurttaslik ve Demokrasi Dliskisi" (Kemalist Republicanism, Citizenship and Democracy), Varlik, 1069, October 1996, pp. 2-8, esp. 6. See also the papers and discussions in Türkiye'de Dnsan Haklari Semineri (Seminar on Human Rights in Turkey), 9-11 Aralik 1968, Tebligler, Tartismalar (Papers, Discussions), Ankara Üniversitesi, Hukuk Fakültesi Publications, 256, Kamu Hukuku ve Siyasal Bilim Enstitüsü Yayinlari 1, Ankara, 1970, esp. p. 65.

15. Hans Kohn considers these years the formative years of French and German nationalisms. Hans Kohn, Prelude to Nation-states: The French and the German Experience, 1789-1815, D. Van Nostrand Company, Inc., New Jersey, 1967.

16. William Rogers Brubaker, Citizenship and Nationhood in France and Germany, Harvard University Press, Cambridge, MA, London, England, 1992, p. 10. See also William Rogers Brubaker, "Immigration, Citizenship, and the Nation-state in France and Germany: A Comparative Historical Analysis", International Sociology, vol. 5, no. 4, pp. 379-407, December 1990; William Rogers Brubaker, Immigration and the Politics of Citizenship in Europe and North America, German Marshall Fund of the United States and University Press of America, 1989.

17. William Rogers Brubaker, Citizenship an Nationhood in France and Germany, p. 8.

18. Ibid., p. 10.

19. I have studied extensively the origins of German nationalism and citizenship earlier. See, for instance, Ayse Kadioglu, "Is Racism Being Combated Effectively in Germany: The New Immigration Legislation", Göran Rystad (ed.), Encountering Strangers: Responses and Consequences, Lund University Press, Sweden, 1996; Ayse Kadioglu, "Devletini Arayan Millet: Almanya Örnegi"; Ayse Kadioglu, "The Human Tie: International Labor Migration", Canan Balkir and Allan M. Williams (eds), Turkey and Europe, Pinter Publishers Ltd. St. Martin's Press, London, New York, 1993; Ayse Kadioglu, "Citizenship, Immigration and Racism in a Unified Germany with Special Reference to the Turkish Guestworkers", Journal of Economics and Administrative Studies, 6/1-2, 1992, Bogaziçi University Publications, pp. 199-211; Ayse Kadioglu, "Tarihsel Açidan Alman Milliyetçiligi, Vatandaslik Kavrami ve Göç Politikalari" (German Nationalism From a Historical Perspective, the Concept of Citizenship and Immigration Policies), Türkiye Günlügü, 17, 1991, pp. 104-109.

20. Ayse Kadioglu, "The Paradox of Turkish Nationalism and the Construction of Official Identity", Middle Eastern Studies, 32/2, April 1996, pp. 177-194.

21. Niyazi Berkes, "Translator's Introduction", Turkish Nationalism and Western Civilization: Selected Essays of Ziya Gökalp, Greenwood Press, Publishers, Westport, Connecticut, 1959, p. 23.

22. See; Ayse Kadioglu, "Milletini Arayan Devlet: Türk Milliyetçiliginin Açmazlari" (A State in Search of Its Nation: The Dilemmas of Turkish Nationalism), Türkiye Günlügü, 33, March-April 1995, pp. 91-101.

23. Adrian Oldfield, "Citizenship: An Unnatural Practice", Bryan Turner and Peter Hamilton (eds), Citizenship: Critical Concepts, vol.1, Routledge, London, New York, 1994; Adrian Oldfield, Citizenship and Community: Civic Republicanism and the Modern World, Routledge, London, New York, 1990.

24. Adrian Oldfield, Citizenship and Community: Civic Republicanism and the Modern World, op.cit., p. 1.

25. Adrian Oldfield, "Citizenship: An Unnatural Practice", op. cit., p. 190. 
26. Adrian Oldfield, Citizenship and Community: Civic Republicanism and the Modern World, op. cit., p. 5.

27. Adrian Oldfield, "Citizenship: An Unnatural Practice", op.cit., p. 192.

28. Ibid., p. 191.

29. Ibid.

30. (my emphasis) Ibid., p. 193.

31. Füsun Üstel, "Cumhuriyet'ten Bu Yana Yurttas Profili" (The Citizen Profile Since the Republic), Yeni Yüzyil (daily), April 24, 1996.

32. Ibid.

33. Fuat Keyman, "Kemalizm, Modernite, Gelenek" (Kemalizm, Modernity, Tradition), Toplum ve Bilim, 72, Spring 1997, pp. 84-99.

34. Ibid., p. 92.

35. Ibid., p. 93. See also, Hasan Bülent Kahraman, "Kemalist Cumhuriyetçilik, Yurttaslik ve Demokrasi Dliskisi", op. cit.

36. Bryan Turner, "Outline of a Theory of Citizenship", op.cit. Bryan Turner, "Contemporary Problems in the Theory of Citizenship", Bryan Turner (ed.), Citizenship and Social Theory, Sage Publications, London, Newbury Park, New Delhi, 1993.

37. Bryan Turner, "Outline of a Thory of Citizenship", op.cit., p. 55.

38. Ibid., p. 46.

39. Ibid., pp. 55-56.

40. Bryan Turner, "Contemporary Problems in the Theory of Citizenship", op.cit., p. 10.

41. Bryan Turner, "Outline of a Theory of Citizenship", op.cit., p. 56.

42. Füsun Üstel "Cumhuriyet'ten Bu Yana Yurttas Profili", op.cit.

43. Immanuel Kant, "An Answer to the Question: What is Enlightenment?", Hans Reiss (ed), Kant's Political Writings, op.cit..

44. (my emphasis) Atatürk'ün Yazdigi Yurttaslik Bilgileri (Citizenship Information Written by Atatürk), Nuran Tezcan (ed.), Çagdas Yayinlari, Istanbul, 1996, p. 17. (my translation).

45. Ibid., p. 54. (my translation).

46. I have elaborated on Ahmet Agaoglu's thought in greater detail in "Secularism and Limits of Liberal Opposition in Turkey", paper prepared for the Annual Meeting of Middle East Studies Association of North America (MESA), November 22-25, 1997, San Francisco.

47. Ahmet Agaoglu, Serbest Firka Hatiralari (Memoirs on Free Republican Party), Dletisim Yayinlari, Istanbul, 1994.

48. Ahmet Agaoglu, Devlet ve Fert (Sate and the Individual), Sanayii Nefise Matbaasi, Istanbul, 1933, p. 27 (my translation).

49. Ahmet Agaoglu, Ben Neyim? (Who am I?), Istanbul, 1939.

50. Ibid., p. 15.

51. Ahmet Agaoglu, "Özcülük ve Özgecilik" (Egoism and Altruism), Akin, May 30, 1933.

52. Ahmet Agaoglu, "Serbest Kadin" (Free Woman), Akin, June 25, 1933.

53. Such a feature of Agaoglu's thought is depicted in a very eloquent article by François Georgeon, "Ahmet Agaoglu: Aydinlanma ve Devrim Hayrani Bir Türk Aydini" (Ahmet Agaoglu: A Turkish Intellectual who Admired Enlightenment and Revolution), Toplumsal Tarih, December 1996, no. 36, pp. 28-35, esp. 32.

54. Ahmet Agaoglu, "Entellektüellerin Zaaflari" (Weaknesses of the Intellectuals), Akin, June 7, 1933. See also, the allegations that he directed to one of the key literary and political figures of his time, Yakub Kadri Karaosmanoglu in Devlet ve Kadro, pp. 119-125.

55. Ahmet Agaoglu, Serbest Dnsanlar Ülkesinde (In the Land of the Free Men), Istanbul, 1936.

56. Henri Bergson's works became quite influential among the intellectuals in Istanbul in the 1920s. On "Bergsonizm", see, Hilmi Ziya Ülken, Türkiye'de Çagdas Düsünce Tarihi (The History of Contemporary Thought in Turkey), Ülken Yayinlari, Istanbul, 1979. One of the common 
denominators of the followers of Bergson was their stance against the positivist views of Ziya Gökalp. Although Agaoglu embraced this positivism, he at the same time harboured some Bergsonian ideas. This should account for some of the apparent paradoxes in Agaoglu's thought such as his love and hate relationship with both the intellectuals and the people.

57. Samet Agaoglu, Babamin Arkadaslari (My Father's Friends), Nebioglu Yayinevi, Istanbul, no date.

58. Ahmet Agaoglu, Serbest Dnsanlar Ülkesinde, p. 75; see also, Agaoglu's description of the cleansing of the spirit in Tanri Daginda (On God's Mountain), (text attached to Ben Neyim?), Istanbul, p. 61.

59. Ahmet Agaoglu, "Nizamli Hürriyet" (Ordered Freedom), Akin, June 5, 1933.

60. I have elaborated on the notion of "Republican epistemology" in Ayse Kadioglu, "Republican Epistemology and Islamic Discourses in Turkey in the 1990s", Muslim World, LXXXVIII/1, January 1998, pp. 1-21.

61. (my emphasis) Hans Reiss (ed.), "Introduction", Kant's Political Writings. 